\title{
Akuntansi Masjid Sebagai Solusi Transparansi Dan Akuntabilitas Publik
}

\author{
Norita Citra Yuliarti \\ FE Universitas Muhammadiyah Jember \\ Email:norita@unmuhjember.ac.id
}

\begin{abstract}
ABSTRAK
Masjid yang merupakan salah satu organisasi sector public, hanya di jadikan sebagai tempat untuk melakukan atau melayani aktivitas ritual peribadatan. Namun, sebenarnya masjid apabila di sadari sebagai salah satu bentuk organisasi yang memiliki peran yang sangat strategis dan peningkatan kesejahteraan masyarakat, seperti pusat aktivitas yang meliputi pendidikan, ekonomi, social, budaya dan hokum. Fenomena yang terjadi di masyarakat bahwa praktik pengelolaan keuangan masjid di dasari oleh kepercayaan, tanpa memiliki system untuk mewujudkan kepercayaan tersebut. Pendanaan masjid di peroleh dari sedekah jamaah, sehingga tanpa pertanggung jawaban keuangan yang jelas dan rinci, otomatis nama baik pengurus berhadapan dengan resiko yang tinggi selain itu citra masjid juga ikut tercemar. Berangkat dari berbagai kritik akuntabilitas masjid bahwa pengendalian internal dan pengawasan pengelolaan keuangan pada organisasi masjid masih lemah, penelitian ini mencoba memberikan solusi terhadap problematika yang terjadi yakni pengaplikasian akuntansi masjid. Berawal dari problematika yang di hadapi oleh masjid terutama Masjid Al Qolam yakni belum adanya pertanggungjawaban yang rinci dan jelas terhadap dana umat terutama karena sumber keuangan Masjid Al Qolam berasal dari berbagai pihak, maka penelitian ini akan mengeksplorasi penerapan akuntansi di Masjid Al Qolam selama ini dan memberikan solusi yang tepat untuk meningkatkan transparansi dan akuntabilitas public Masjid Al Qolam.
\end{abstract}

Kata Kunci : masjid, akuntabilitas dan transparansi, akuntansi masjid

\begin{abstract}
The mosque, which is one of the public sector organizations, is only made as a place to perform or serve ritual worship activities. However, the mosque is actually realized as one form of organization that has a very strategic role and enhances the welfare of the community, such as the center of activities that includes education, economy, social, culture and law. Phenomenon that occurs in the community that the practice of managing mosque finance is based on trust, without having a system to realize that trust. Mosque finance was obtained from charity pilgrims, so that without clear and detailed financial accountability, the management's good name was faced with high risks besides the image of the mosque was also polluted. Departing from various criticisms of mosque accountability that internal control and supervision of financial management in mosque organizations are still weak, this study tries to provide a solution to the problems that occur, namely the application of mosque accounting. Starting from the problems faced by mosques, especially the Al Qolam Mosque, namely the absence of detailed and clear accountability for the people's funds, especially because the financial resources of Al Qolam Mosque come from various parties, this study will explore the application of accounting in the $\mathrm{Al}$ Qolam Mosque so far and provide the right solution to increase transparency and accountability of the Al Qolam Mosque public.
\end{abstract}

Keywords: mosque, accountability and transparency, mosque accounting 


\section{PENDAHULUAN}

Indonesia merupakan negara Islam terbesar di dunia. Lebih dari $80 \%$ penduduk di Indonesia beragama Islam. Masjid merupakan tempat yang tidak mungkin terpisahkan di kehidupan umat Islam. Masjid berasal dari bahasa Arab yakni sajada yang berarti tempat sujud atau tempat menyembah Allah SWT (Ayub, 1996). Berdasarkan klasifikasinya, masjid menurut Kementrian Agama Republik Indonesia terdiri dari Masjid Raya, Masjid Besar, Masjid Bersejarah, Masjid Agung, Masjid Jami, dan Masjid di Tempat Publik dengan total jumlah keseluruhan masjid hingga tahun 2017 berjumlah 215.815 masjid yang tersebar di Indonesia.

\section{Grafik 1.1 DATA JUMLAH MASJID DI INDONESIA}

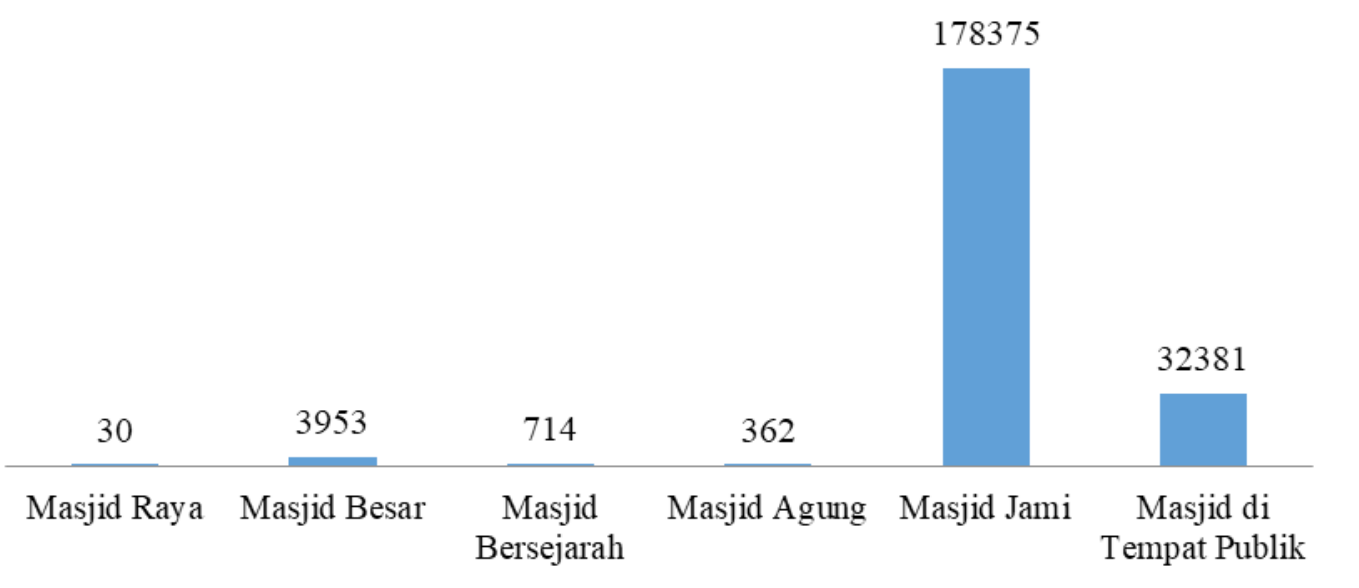

Sumber: http://simas.kemenag.go.id/

Masjid yang merupakan salah satu organsasi sektor publik hanya dijadikan sebagai tempat untuk melakukan atau melayani aktivitas ritual peribadatan. Namun, sebenarnya masjid apabila disadari sebagai salah satu bentuk organisasi memiliki peranan yang sangat strategis dalam peningkatan kesejahteraan masyarakat, seperti pusat aktivitas yang meliputi pendidikan, ekonomi, sosial, budaya, dan hukum (Halim dan Kusufi, 2016). Dijelaskan oleh Ayub (1996) dalam konteks organisasi masjid, bahwa keuangan masjid meliputi cara mengumpulkan dana, sumber pendanaan, pengelolaan, dan pertanggungjawaban dana masjid.

Dewasa ini, muncul problematika yang dihadapi oleh masjid yang berkaitan dengan pengurus, kegiatan, maupun kegiatan yang berkenaan dengan jamaah, yang dapat menyebabkan terhambatnya kemajuan dan kemakmuran masjid. Fenomena yang terjadi di masyarakat bahwa praktik pengelolaan keuangan masjid didasari oleh kepercayaan (trust agency) tanpa memiliki sistem untuk mewujudkan kepercayaan tersebut (Simanjuntak dan Januarsi, 2011). Senada dengan hal tersebut Halim dan Kusufi (2016) menjelskan bahwa keuangan masjid diperoleh dari sedekah jamaah, sehingga tanpa pertanggungjawaban keuangan yang jelas dan rinci, otomatis nama baik pengurus berhadapan dengan risiko yang tinggi selain itu citra masjid bisa saja ikut tercemar. Memelihara citra masjid memang tidak mudah dan mengingat manusia memiliki banyak kelemahan (khilaf dan salah), tak terkecuali jamaah dan para 
pengurus masjid sehingga transparansi dan akuntabilitas penting dalam organisasi masjid dan harus dilaksanakan dengan baik (Halim dan Kusufi, 2016).

Dari berbagai problematika tersebut kemudian muncul pertanyaan, bagaimana meyakinkan umat bahwa dana umat telah dikelola dengan tepat? Berangkat dari berbagai kritik terhadap akuntabilitas masjid bahwa pengendalian internal dan pengawasan pengelolaan keuangan pada organisasi masjid masih lemah (Mohamed et al., 2014), penelitian ini mencoba memberikan solusi terhadap problematika yang terjadi yakni dengan pengaplikasian akuntansi masjid. Akuntansi dapat juga dijadikan sebagai alat untuk mengembangkan fungsi dan peran masjid selain untuk tempat peribadatan seperti peran untuk mencerdaskan umat (Halim dan Kusufi, 2016). Lebih lanjut dijelaskan oleh Halim dan Kusufi (2016) bahwa akuntansi masjid dapat diartikan sebagai tata buku atau rangkaian kegiatan yang dilakukan secara sistematis dalam bidang keuangan, berdasarkan prinsip, standardisasi, dan prosedur tertentu untuk menghasilkan informasi aktual di bidang keuangan dalam organisasi masjid yang melibatkan para anggota, umat, atau pengikut agama di organisasi keagamaan yang bersangkutan. Problematika inilah yang terjadi pula pada Masjid Al-Qolam. Masjid AlQolam merupakan masjid di tempat publik, yang terletak di Jalan Karimata No. 49 Jember tepatnya berada di Universitas Muhammadiyah Jember. Selama ini sumber keuangan masjid berasal dari sumbangan masyarakat (infaq dan sedekah), sumbangan perorangan (nazar), sumbangan universitas, dan sumbangan dari PP Muhammadiyah Jember. Laporan kas yang dibuat oleh pengurus masjid masih sangat sederhana yaitu dengan bentuk empat kolom yaitu uraian, penerimaan, pengeluaran dan saldo. Pada Masjid Al-Qolam belum dilakukan publikasi terhadap laporan kas yang dibuat oleh pengurus.

Berangkat dari problematika yang dihadapi oleh masjid terutama Masjid AlQolam yakni belum adanya pertanggungjawaban yang rinci dan jelas terhadap dana umat terutama karena sumber keuangan Masjid Al-Qolam berasal dari sumbangan berbagai pihak, maka penelitian ini akan mengeksplorasi penerapan akuntansi di Masjid Al-Qolam selama ini dan memberikan solusi yang tepat untuk meningkatkan transparansi dan akuntabilitas publik Masjid Al-Qolam.

\section{TINJAUAN PUSTAKA}

\section{Masjid}

Masjid berasal dari bahasa Arab yakni sajada yang berarti tempat sujud atau tempat menyembah Allah SWT (Ayub, 1996). Fungsi utama masjid adalah tempat sujud kepada Allah SWT, tempat shalat, dan tempat beribadah kepada-Nya dimana masjid merupakan tempat yang paling banyak dikumandangkan nama Allah melalui adzan, qamat, tasbih, tahmid, tahlil, istigfar, dan ucapan lain yang dianjurkan dibaca masjid sebagai lafaz yang berkaitan dengan pengagungan asma Allah (Ayub, 1996). Dalam perkembanganya, masjid mulai memperhatikan kipral operasional menuju keagamaan dan kesempurnaan kegiatan, dimana operasionalisasi masjid menyangkut (Ayub, 1996):

1. Aspek hissiyah (bangunan) 
Dalam masalah bangunan fisik masjid, Islam tidak menentukan dan mengaturnya artinya umat Islam diberikan kebebasan, sepanjang bangunan masjid itu berperan sebagai rumah ibadah dan pusat ibadah.

\section{Aspek maknawiyah (tujuan)}

Pada masa Nabi Muhammad saw., masjid dibangun atas dasar takwa (atTaubah: 108) sebagai pusat ibadah dan pusat pembinaan umat dan atas dasar permusuhan dan perpecahan (at-Taubah: 107-108) dengan maksud untuk memecah belah umat sehingga atas dasar permusuhan dan perpecahan inilah Allah SWT memerintahkan Nabi Muhammad saw. untuk menghancurkan masjid tersebut.

\section{Aspek ijtima'iyah (segala kegiatan)}

Aspek kegiatan masjid dilihat dari ruang lingkup kelembagaan masjid yakni lembaga dakwah dan bakti sosial, lembaga manajemen, dan dana serta lembaga pengelola dan jamaah.

\section{Akuntansi Masjid}

Akuntansi masjid dapat diartikan sebagai tata buku atau rangkaian kegiatan yang dilakukan secara sistematis dalam bidang keuangan, berdasarkan prinsip, standardisasi, dan prosedur tertentu untuk menghasilkan informasi aktual di bidang keuangan dalam organisasi masjid yang melibatkan para anggota, umat, atau pengikut agama di organisasi keagamaan yang bersangkutan (Halim dan Kusufi, 2016). Peran akuntansi akan terlihat jika tempat ibadah atau masjid diposisikan sebagai entitas atau satuan organisasi (Halim dan Kusufi, 2016). Mengenalkan akuntansi pada organisasi masjid berarti lebih berorientasi untuk menumbuhkan kesadaran kepada pengelola masjid tentang pentingnya praktik akuntansi dalam pengembangan organisasi masjid (Halim dan Kusufi, 2016). Akuntansi dijadikan pengurus masjid sebagai tools positif secara material tetapi distortif bagi teologi Islam (Simanjuntak dan Januarsi, 2011).

\section{Transparansi dan Akuntabilitas Publik}

Bagaimana akuntabilitas pada organisasi masjid? Pada organisasi sektor publik, termasuk organisasi keagamaan, pengelola (pengurus dan pengawas) organisasi bertanggung jawab kepada umat atau pengikut agama yang disampaikan dalam sebuah pertemuan perwakilan umat atau warga atau rapat dengan warga masyarakat yang menggunakan organisasi keagamaan secara berkala (Halim dan Kusufi, 2016). Hal ini mengindikasikan bahwa untuk mencapai akuntabilitas, dibutuhkan pula transparasi antara pihak pengelola dan umat. Keterbukaan atau transparansi tidak akan tercipta apabila pengurus bersifat tertutup sehingga diharapkan pengurus masjid harus bersifat terbuka dan memiliki keterbukaan (Ayub, 1996). Dengan adanya keterbukaan umat akan merasa ikhlas dalam menyumbangkan pemikiran, senang turut melaksanakan berbagai kegiatan, dan terlibat dalam mengatasi problematika masjid maka interaksi yang demikian akan memajukan dan memakmurkan masjid (Ayub, 1996). Menerapkan transparansi atau keterbukaan dalam mengelola masjid dibutuhkan dalam melaksanakan berbagai kegiatan maupun dalam mengatasi berbagai problematika masjid (Ayub, 1996). Transparansi publik dapat dilakukan dengan menggunakan akuntansi sebagai alatnya. Dengan adanya akuntansi, akan tercipta 
transparansi diantara pihak agent (pengurus atau pengelola organisasi publik) dan principal (stakeholder) sehingga tidak tercipta asimetri informasi ataupun moral hazard dalam organisasi sektor publik tersebut.

\section{METODE PENELITIAN}

Metode pelaksanaan penelitian ini diselenggarakan dengan metode ceramah, diskusi, dan praktik. Metode ceramah dan diskusi diperuntukkan bagi para pengurus masjid untuk memberikan wawasan mengenai akuntansi masjid. Metode praktik dilakukan agar pengurus masjid memahami bentuk baku dari laporan keuangan untuk masjid. Output pada metode ceramah, diskusi dan praktik ini diharapkan para pengurus masjid dapat menerapkan akuntansi masjid dan dapat membuat laporan keuangan masjid. Selain itu, output pada penelitian ini adalah adanya publikasi laporan keuangan secara berkala melalui website Universitas Muhammadiyah.

Alur penelitian

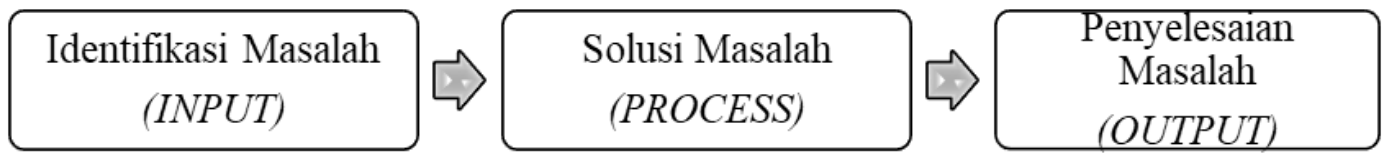

HASIL DAN PEMBAHASAN

\section{Akuntansi Masjid}

Islam sangat erat sekali kaitannya dengan pencatatan dan akuntansi.Ada banyak hal dalam Islam yang berhubungan dengan pencatatan, perhitungan dan akuntansi, utang dan zakat.Ilmu akuntansi tersebut sudah ada sejak masa Rasulullah SAW yang ditandai dengan turunnya Surat Al-Baqarah Ayat 282. Dari situlah dapat disimpulkan bahwa pencatatan dalam Islam itu signifikansi, pencatatan itu dapat menjadikan entitas keagamaan dapat bekerja dengan baik.Pencatatan keuangan dalam suatu entitas keagamaan (Masjid) dapat menjadi ukuran kinerja para pengurus Masjid atau Takmir Masjid khususnya yang diamanahkan sebagai bendahara keuangan.Penelitian yang dilakukan oleh Kerry Jacob (2004) dalam Simanjutak dan Januarsih (2011) yang menjelaskan bahwa akuntansi mampu mendorong kerja entitas keagamaan menjadi lebih baik ketika peran akuntansi di maksimalkan di lembaga keagamaan tersebut. Pernyataan yang senada seperti yang disampaikan Ketua Takmir Masjid, Amir Fatah. "Perlu sekali, karena pencatatan keuangan yang modern itu pasti akuntansi berperan penting dan diperlukan untuk laporan keuangan supaya tertata baik dan juga memperlihatkan adanya transparansi kepada jama'ah dan semua pengurus Masjid Nurul Huda, saya kira itu sangat penting sekali, hanya wujudnya (model pencatatan keuangan) barang kali itu kurang baik, tidak seperti yang ada di universitas atau yang lain, karena pengurus - pengurus di sini mungkin perlu belajar lagi (dalam melakukan pencatatan). Malah terima kasih sekali ada penelitian seperti ini." Ketua Takmir Masjid sadar betul peran akuntansi dalam pencatatan keuangan Masjid, dimana pencatatan tersebut sebagai bukti akuntabilitas dan transparansi yang dilakukan Takmir Masjid untuk menjadikan entitas keagamaan menjadi lebih 
baik.Pencatatan tersebut sebagai bentuk tanggung jawab Takmir Masjid kepada semua Jama'ah Masjid karena telah diamanahkan. Selain itu pencatatan dapat dijadikan bukti bahwa bendahara sudah bekerja dengan sebaik mungkin dan apabila terjadi kecurigaan dari jama'ah dapat dijelaskan semua aliran

uang masuk dan keluar secara detail dan dengan bukti-bukti yang bisa dipertanggungjawabkan.

\section{Teologi Islam}

Akuntansi dalam entitas keagamaan memang terdengar seperti dua hal yang tidak memiliki keterkaitan yang baik, apalagi bagi orang awam. Namun semakin berkembangkanya ilmu akuntansi saat ini dan juga kebutuhan publik akan hal tersebut, maka akuntansi atau pencatatan dengan model tradisional sudah diterapkan banyak entitas keagamaan yang menggunakannya dalam melakukan pencatatan keuangannya. Namun tak sedikit pula entitas keagamaan yang sudah melakukan pencatatan keuangan dengan metode yang diterapkan seperti pada suatu perusahaan dan lainnya. Pencataatan tersebut digunakan untuk kemajuan entitas keagamaan dan sebenar-benarnya hal itu menjadi sebuah keharusan. Hal senada juga terucap dari pernyataan Ketua Takmir Masjid, bermanfaat sekali, sebab kalau kita bicara keuangan itu kan istilah orang jawa mengatakan riwil (rawan), kalau laporannya tidak baik, tidak mudah dibaca, tidak semua jama'ah mengerti, yang seperti itu pasti akan menjadi fitnah, dan kita tidak menginginkan itu, jadi manfaat dari laporan keuangan secara akuntansi atau dalam keuangan itu sangat penting sekali supaya mudah dipahami oleh semua pengurus dan jama'ah." Kalimat yang terucap diatas mengungkapkan bahwa pencatatan keuangan dalam Masjid Al Qolam sangat bermanfaat bagi kelancaran tugas Takmir Masjid. Pencatatan tersebut juga sebagai bentuk kinerja Takmir Masjid karena telah diamanahkan oleh para jama'ah dan sebagai bukti keuangan sudah dicatatn dengan sebaik dan sejujur-jujurnya agar tidak terjadi fitnah atau kecurigaan.

\section{Pengelolaan Keuangan Masjid dan Akuntabilitas Publik}

\section{Pengelolaan Keuangan Masjid}

Pencatatan keuangan di Masjid Al Qolam tidaklah seperti pencatatan keuangan pada umumnya, tetapi walaupun pencatatan tersebut sangatlah sederhana namun ini berlangsung cukup lama dan menjadi bukti kinerja dan bukti keluar masuknya keuangan Masjid yang valid, karena setiap pengeluaran mempunyai bukti kuitansi, uang masuk pun tiap pendapatan dihitung secara bersama jadi cukup bisa menjadi bukti transparansi. Masjid Al Qolam terletak di lingkungan Universitas Muhammadiyah Jember, Jadi semua pelaporan keuangan selain di laporkan kepada jamaah masjid juga harus di laporkan kepada Universitas Muhammadiyah Jember. Hasil laporan juga dibuatkan dalam bentuk print out yang di bacakan pada pengumuman Masjid, yang bisa dibaca oleh semua jama'ah sebagai wujud akuntabilitas dan transparansi pengurus kepada jama'ah.

Pencatatan tradisional yang dipraktekkan di Masjid Al Qolam memang sudah baik. Selain transaksi yang cukup sedikit dan didominasi oleh pendapatan infaq jum'at, 
pengeluaran biaya kebersihan, model pencatatan tersebut cukup efektif dan mudah dipahami oleh seluruh jama'ah. Bila

sudah diterapkan model pencatatan modern atau pencatatan yang berlaku maka akan banyak jama'ah yang tidak bisa membaca hasil laporan yang begitu detail dan menyeluruh, namun mereka tidak mempunyai SDM yang memadai dan mungkin juga karena mereka tidak memiliki tingkat pendidikan di bidang keuangan. Maka metode tradisional dan mudah di pahami menjadi pilihan pengurus yang juga belum memahami pencatatan yang resmi.

\section{Transparansi Keuangan Masjid}

Pada Masjid Al Qolam ini keuangan masjid terbagi menjadi dua : 1).Keuangan masjid dari dana Universitas dan 2). Keuangan masjid dari dana Infaq.

Transparansi keuangan masjid dalam pengelolaan keuangan sangat diperlukan sekali oleh pengurus kepada jama'ah dan Universitas Muhammadiyah Jember. Dana yang dikelola oleh Masjid Al Qolam adalah dana infaq, sedangkan dana untuk mebangun masjid dan perbaikan masjid dana di berikan oleh Universitas Muhammadiyah Jember. Karena jama'ah dan pihak universitas mempunyai hak untuk mengetahui arus kas Masjid, sementara pengurus mempunyai kewajiban untuk menyampaikan arus kas Masjid. Dalam wawancara pengurus masjid mengucapkan hal sebagai berikut: "Setiap pengurus mengetahui tentang pencatatan tersebut, karena setiap rapat diberi tahu, kemudian kalau tidak jelas bisa ditanyakan. Jadi setiap akan mengeluarkan uang, biasanya pengurus mengadakan rapat, kemudian setelah setiap kegunaan-kegunaan juga dilaporkan, misalnya akan membeli barang-barang untuk masjid itu pengurus mengadakan rapat dulu. Nanti begitu habis berapa, kita laporkan setelah selesai pembangunan itu, sehingga keadaan uang itu akan terpantau terus baik yang ada, keluar berapa, kemudian masih ada berapa, itu pengurus harus tahu itu." Dan juga, "Yang jelas pengurus harus tahu dan kemudian warga juga secara terbuka harus diberi pengertian melalui papan-papan yang ada di Masjid, itu cara kita mensosialisasikan keadaan keuangan Masjid tersebut." Penekanan dari hasil wawancara tersebut, lebih menekankan pada pentingnya transparansi, baik kepada pengurus maupun kepada jama'ah Masjid Al Qolam berserta Universitas Muhammadiyah Jember. Selain penyampaian laporan keuangan pada akhir periode dalam rapat, pengurus hanya membacakan laporan keuangan tersebut.

\section{Akuntabilitas Publik}

Akuntabilitas publik adalah kewajiban penerima tanggungjawab untuk mengelola sumber daya, melaporkan, dan mengungkapkan segala aktivitas dan kegiatan yang berkaitan dengan penggunaan sumber daya public kepada pihak pemberi mandate (principal). Akuntabilitas berbeda dengan konsep responsibiitas (Mahmudi, 2005:9) dalam (Simanjutak dan Januarsih, 2009:7). Sedangkan pertanggung jawaban yang disampaikan oleh Ketua Takmir Masjid, mengarah pada semua pengurus kerena 
bagaimanapun mereka adalah satu organisasi yang harus bekerja sama dalam menjalankan semua

kegiatan termasuk didalamnya yaitu pengelolaan keuangan Masjid. Namun bendahara tetap memiliki tugas yang lebih dalam pengelolaan tersebut dan harus memberikan laporan keuangan kepada pengurus lain dan juga jama'ah. Hal tersebut terucap langsung oleh Ketua Takmir Masjid Al Qolam.

\section{KESIMPULAN DAN SARAN}

Akuntansi dalam pengelolaan keuangan Masjid disadari oleh para pengurus Masjid memiliki peran yang sangat penting. Walaupun metode yang dipakai masih sederhana, namun pencatatan tersebut sebagai bukti akan aliran kas Masjid dan juga sebagai bukti kinerja para pengurus dalam pertanggung jawaban atas amanah yang diberikan. Dengan pencatatan yang baik maka diharapkan semua jama'ah dapat memahami catatan yang dibuat dan menghindarkan dari berbagai hal- hal negatif yang mungkin terjadi. Jadi dapat disimpulkan bahwa praktek akuntansi dijalankan oleh Takmir Masjid Al Qolam

Model pengelolaan yang dipakai oleh pengurus Masjid yaitu model pencatatan sederhana, yaitu mencatan aliran kas masuk dam aliran kas keluar lalu dijumlahkan untuk menghasilkan jumlah saldo. Walaupun pencatatannya masih sederhana namun dalam prakteknya dapat berjalan dengan baik dan tidak pernah ditemukan masalah. Walaupun jama'ah sudah sangat percaya dengan para pengurus, namun dalam prakteknya para pengurus tetap bertanggung jawab (akuntabilitas) dengan apa yang dikerjakan dan terbuka (transparansi) dalam hal pencatatannya. Jadi dapat disimpulkan bahwa pengelolaan keuangan dan akuntabilitas public sudah dijalankan oleh Takmir Masjid Al Qolam.

Peneliti berharap kepada peneliti selanjutnya untuk melakukanpenelitian yang lebih mendalam lagi, baik dari segi wawancara kepada informan maupun pengolahan data dengan referensi yang lebih banyak, bahkan objek penelitian bisa di perbanyak untuk dibandingkan dengan metode pencatatan yang lain, dan tentunya untuk mengembangkan lagi metode pengelolaan keuangan Masjid yang lebih baik.

\section{DAFTAR PUSTAKA}

Ayub, M.E. 1996. Manajemen Masjid. Jakarta: Gema Insani Press.

Indra, Bastian. 2008. Akuntansi Sekot Publik. Jakarta: Salemba Empat

Mohamed, I. S, N.H.A. Aziz, M.N. Masrek, dan N.M. Daud. 2014. Mosque Fund

Management: Issues on Accountability and Internal Controls. ProcediaSocial and Behavioral Sciences, Vol. 145, hlm. 189-194. 
Mardiasmo, 2009.Akuntansi Sekot Publik. Yogyakarta: Andi.

Mardiasmo. 2006. Pewujudan Transparansi dan Akuntabilitas Publik Melalui Akuntansi Sektor Publik: Suatu Sarana Good Governance. Jurnal Akuntasi Pemerintah ,Vol. 2, No. 1. Hal 1 - 17.

Moleong, L.J.2005.Metodologi Penelitian Kualitatif. Edisi Revisi. PT Remaja.Rosdakarya. Bandung

Rahayu, Sri. Ludigdo dan Affandy.2007. Studi Fenomenologis Terhadap Proses Penyusunan Anggaran Daerah Bukti Empiris Dari Satu Satuan Kerja Perangkat Daerah Di Provinsi Jambi.Simposium Nasional Aakuntansi X Makasar. 2007. ASPP03

Randa, F. 2011.Rekonstruksi Konsep Akuntabilitas Organisasi Gereja: (Studi Etnografi Kritis Inkulturatif pada Gereja Katolik di Tana Toraja). Symposium Nasional Akuntansi XIVAceh 2011.21-22 Juli.1-39.

Setiyani, H. 2011. Studi Fenomenologis Terhadap Proses Penyusunan Anggran Di Kabupaten Klaten.Skripsi.Program S1 Ekonomi Akuntansi Universitas Muhammadiyah Surakarta. Silvia, J. 2011.Akuntabilitas Dalam Perspektif Gereja Protestan (Studi Fenomologis Pada Gereja Protestan Indonesia Dongala Jemaat Manunggal Palu). Symposium Nasional Akuntansi XIVAceh 2011.21-22 Juli.1-25.

Simanjuntak, D. A., dan Januarsi, Y. 2011. Akuntabilitas dan Pengelolaan Keuangan di Masjid. Simposium Nasional Akuntansi XIV Aceh.

Siskawati, E., Ferdawati, dan Surya F. 2016. Bagaimana Masjid Dan Masyarakat Saling Memakmurkan? Pemaknaan Akuntabilitas Masjid. Jurnal Akuntansi Multiparadigma, 7(1), 70-80

Yahya, I. 2006. Akuntabilitas dan Pengelolaan Keuangan Daerah. Jurnal Sistem Teknik Industri, Vol.7, No.4. 